DOI: $10.14720 /$ aas.2016.107.1.08

Agrovoc descriptors: microwave radiation; seed treatment; disease control; aspergillus niger; seed vigour; seed viability ; seed characteristics; germinability; oil crops; rapeseed; soybeans; safflower

Agris category code: F03, h01, q04

\title{
Effect of microwave radiation on seed viability, survival of Aspergillus niger van Tieghem and oil quality of oilseeds crops canola, soybean and safflower
}

Ahad MOTALLEBI ${ }^{1}$

\begin{abstract}
Received August 24, 2015; accepted November 16, 2015.
Delo je prispelo 24. avgusta 2015, sprejeto 16. novembra 2016.

\section{ABSTRACT}

The effect of microwave's radiation on seed viability of three different oilseed crops, spores of Aspergillus niger and quality of extracted oil from treated seeds over various exposure times was evaluated. The seeds were exposed to $2450 \mathrm{MHz}$. at five different power levels of $0,100,200,400,600$ and $800 \mathrm{~W}$ for two exposure times of three and five minutes. At a given time, a direct negative relationship between seed viability and microwave's radiation power level was detected. Substantial variation in the lethality of tested seeds to microwave's power levels was apparent in the fiducial limits of the estimated $\mathrm{LD}_{50}$ values in probit analysis approach. A similar trend of $A$. niger spores' susceptibility to microwave radiation was detected. The microwaves' radiation and exposure time did not impact one another and a significant interaction was not detected. Short term fungal infection did not cause substantial quantitative and qualitative damage to the oilseeds. The oil quality was generally unaffected by microwave radiation and fungal infestation for tested oilseeds. Moreover, microwave radiation decreased seed germination percentage and vigor index. The microwave radiation could provide an effective and friendly environmental treatment technique for improving the dietary consumption of the oil in any seed disinfestation program.
\end{abstract}

Key words: disinfestation, microwave, Aspergillus niger, vigor index, oil composition, canola, soybean, safflower

\section{IZVLEČEK}

\author{
VPLIV MIKROVALOVNEGA SEVANJA NA \\ VIABILNOST SEMEN, PREŽIVETJE GLIVE \\ Aspergillus niger van Tieghem IN KVALITETO OLJA \\ OLJNE OGRŠČICE, SOJE IN ŽAFRANIKE
}

$\mathrm{V}$ raziskavi je bil preučevan učinek mikrovalovnega sevanja na viabilnost semen treh oljaric, preživetje spor glive Aspergillus niger in kakovost olja, pridobljenega iz tretiranih semen v odvisnosti od časa izpostavitve. Semena so bila izpostavljena mikrovalovnemu sevanju $2450 \mathrm{MHz}$ s petimi stopnjami moči $(0,100,200,400,600$ in $800 \mathrm{~W})$ za čas treh in pet minut. Po določenem času tretmaja je bila ugotovljena neposredna negativna povezava med viabilnostjo semen in močjo mikrovalovnega sevanja. Očitna je bila znatna variabilnost $\mathrm{v}$ smrtnosti testiranih semen glede na moč mikrovalovnega sevanja, statistično ovrednotena kot standardne $\mathrm{LD}_{50}$ vrednosti. Podoben trend občutljivosti na mikrovalovno sevanje so pokazale tudi spore glive $A$. niger. Mikrovalovno sevanjem in čas izpostavitve semen nista vplivala drug na drugega, značilna interakcija ni bila ugotovljena. Kratkotrajna okužba semen z glivami ni povzročila večjih kakovostnih in količinskih izgub. Kvaliteta olja vseh tretiranih semen oljaric je bila $\mathrm{v}$ glavnem nespremenjena po mikrovalovnem obsevanju in okužbo $\mathrm{Z}$ glivo. Mikrovalovno obsevanje je zmanšalo odstotek kalitve in vitalnostni indeks vseh tretiranih semen. Mikrovalovno obsevanje lahko nudi učinkovit in okolju prijazen način izboljšanja ohranjanja olj $\mathrm{v}$ prehrani $\mathrm{v}$ kateremkoli dezinfekcijskem programu semen.

Ključne besede: dezinfekcija, mikrovalovi, Aspergillus niger, vitalnostni indeks, sestava olj, oljna ogrščica, soja, žafranika 


\section{INTRODUCTION}

Microwave's energy is not persistent in the environment and does not have hazardous impacts or damage to a foodstuff (Vadivambal et al., 2007). Radiation has been recognized as a cheap, safe and effective technique for food preservation among all existing techniques (Bangash et al., 2007). In this line, Bangash et al. (2007) as well as Kumar and Viswanathan (2013) stated that the stability of many edible oils such as canola has been improved by irradiation treatment. Temperature is one of the principal factors delimitating survival and reproduction of fungal spores. Lethal temperatures are those above or below the suboptimum which will eventually kill the organism. Decontamination through temperature manipulation is receiving renewed interest as a non-chemical method with lack of a residue problem (Hallman and Denlinger, 1999).

Fungi can be controlled by manipulating the physical environment or by applying physical treatments to the infested oilseed. Fungal spores are abundant in the atmosphere and settle on to surfaces, can grow and form colonies depending on the physicochemical environmental conditions (Christofi et al., 2008; Ehrensing, 2008). Many surfaces, including oilseeds become infested; therefore, it is a requirement for effective disinfestations (Christofi et al., 2008). In this line, Afolabi et al., (2015) stated that microwave radiation could detoxify seed oil and improve its dietary and industrial use. Organisms under microwave's irradiation are prone to some types of stress such as controlled atmosphere and cold ambient (Wang and Tang, 2001). The warehouse environment is usually one that is enclosed, allowing for the manipulation of temperature. Thus, the use of temperature to restrict fungal growth is an excellent tool for the stored-product industry. Exposure to temperatures only $5{ }^{\circ} \mathrm{C}$ above the optimum are capable of slowing down or stopping fungal activity and development and depending on the species, are capable of causing death. The review of the literature revealed the scarcity of information concern over optimal power levels of microwave's radiation combined with the exposure period in oilseeds disinfestations and fungal control programs. To clarify the interaction issue, the present investigation was undertaken. The purpose of this study is specifically to evaluate the effect of microwave radiation on the viability of $A$. niger spores, the quality of oil, oilseed germination, and seedling vigor index.

\section{MATERIALS AND METHODS}

The study was conducted at the Urmia University, Urmia $\left(37.34{ }^{\circ} \mathrm{N} 44.58^{\circ} \mathrm{E}\right.$ and altitude $\left.1365 \mathrm{~m}\right) \mathrm{a}$ town in Iran in 2015. All the experiments were conducted using a kitchen type, $2450 \mathrm{MHz}$ microwaves oven (Butane, BC $320 \mathrm{~W}$, Butane Co., Tehran, Iran) with capability of producing 100 through $1000 \mathrm{~W}$ microwave power. The experimental units and bioassay procedures were identical in all trials. In each trial, the control petri plates were treated identically except that no microwave radiation treatment was employed.

\subsection{Fungal isolate}

An isolate of Aspergillus niger van Tieghem, Ani109, was provided by mycology laboratory of Urmia university which was isolated from canola (Brassica napus 'Okapi') seeds. The fungus was grown on potato dextrose agar (PDA, Merck) medium (9 $\mathrm{cm}$ diameter Petri plates) and incubated at $25^{\circ} \mathrm{C}$ for 7 days in the dark for full sporulation. Spores were scrapped with a sterilized scalpel from the medium and suspended in distilled sterile water containing $0.1 \%$ Trition X100. Suspension was passed through double layer sterile cheese cloth to remove mycelia and medium debris and the concentration of the suspension was adjusted to $1 \times 10^{6} \mathrm{spore} / \mathrm{ml}$ with a neubauer haemocytometer.

\subsection{Bioassays}

Seeds of three oilseed crops viz. canola (Brassica napus 'Okapi'), soybean (Glycine max 'Williams') and safflower (Carthamus tinctorius 'Goldasht') were treated with a suspension of $1 \times 10^{6}$ spore $/ \mathrm{ml}$ for 15 minutes and then allowed to dry. The amount of the spore suspension was adjusted enough to cover all the seeds and seeds were 
agitated three times with a sterile glass rod in order to complete contact with fungal spores. In controls, seeds were treated with distilled water containing $0.1 \%$ Trition X100. To commence oilseed microwave's irradiation, each petri plate $(15 \mathrm{~cm}$ diameter) containing 50 treated seeds was placed in the microwave's oven with capability of producing 100 through $1000 \mathrm{~W}$ microwave's power. For microwave's radiation, five power outputs of the generator were set at 100,200,400, 600 and $800 \mathrm{~W}$. The exposure times were 3 and 5 minutes. After treatments, seed were allowed to germinate under their usual growth conditions for 7 days and the mean shoot length of fifty seedlings was determined at 8 days. Vigor index was calculated using the formula: Vigor index = Germination seed percentage $\times$ seminal root length.

In the case of the effect of irradiation on fungal spore viability, all the treated seeds were transferred into $15 \mathrm{~cm}$ sterilized screw cap test tubes containing $5-10 \mathrm{ml}$ distilled water and $0.1 \%$ Trition X100. Test tubes were agitated vigorously for 5 minutes. One $\mathrm{ml}$ of the suspension was taken with a sterile Pasteur pipette and was sprayed over the PDA medium in $9 \mathrm{~cm}$ Petri plates. Petri plates were incubated at $25{ }^{\circ} \mathrm{C}$ in the dark for $48 \mathrm{~h}$ and were seen under the $40 \mathrm{X}$ magnification. Where the length of the germ tube was more than spore diameter, the spores were counted as germinated, otherwise they were considered dead. Two hundred spores were examined each time. Each test was replicated four times. Mortality data from the replicates were pooled, and mortality response was determined. In order to evaluate the combination's effect of the microwave's power and exposure duration, a factorial experiment with 6 power levels and 2 exposure duration was performed.

\subsection{Oil Extraction and Composition}

For each oil seed crop, a sample of $20 \mathrm{~g}$ of clean seeds was isolated to measure the oil concentrations. Soxhlet extraction technique was employed to determine the total oil concentration of the canola seed and the oil concentration was expressed as $\mathrm{mg} / \mathrm{g}$ (Movahhedy-Dehnavy et al., 2009). The oil concentrations were reported as percent of the seed weight standardized to $9 \%$ moisture. Lipid was extracted from $20 \mathrm{~g}$ of ground seed three times at room temperature by homogenization with hexane/isopropanol $(3: 2 \mathrm{v} / \mathrm{v})$ (St. John and Bell, 1989). The formation of FAME was carried out according to the procedure described by Desvilettes et al (1994). The sample was saponified with methanolic sodium hydroxide and the fatty acids were esterified with methanolic sulfuric acid. FAME were analyzed with a 6890 NGC-FID (Agilent Technologies, Wilmington, DE, USA) fitted with a J \& WDB-Wax capillary column $(30 \mathrm{~m}, 0.25 \mathrm{~mm}$ i.d., $0.25 \mathrm{~mm}$ film thickness), a split-split less inject or with Agilent tape red liner (4 $\mathrm{mm}$ i.d.) and flame ionization detector. The initial column temperature was maintained at $100{ }^{\circ} \mathrm{C}$ for $1 \mathrm{~min}$ and then raised at $25^{\circ} \mathrm{C} / \mathrm{min}$ to $190^{\circ} \mathrm{C}$ and held for $10 \mathrm{~min}$. Nitrogen was used as carrier and make up gas, at flow rates of 1.0 and $45 \mathrm{~mL} / \mathrm{min}$, respectively. The injector and detector temperature were held at $250{ }^{\circ} \mathrm{C}$ and $260{ }^{\circ} \mathrm{C}$, respectively. Chem Stations Software was used for online data collection and processing. Individual FAME was identified by comparison with known standards (Sigma, Chemical Co. St. Louis).

\subsection{Data analysis}

Mortality data from all bioassays were analyzed with SPSS Software (SPSS Inc., 1993). Probit analysis was used to estimate $\mathrm{LD}_{50}$ and $\mathrm{LD}_{95}$ values (watt) and the slopes of the regression lines. The values and significance of $\chi^{2}$ and the $95 \%$ CL were determined according to Robertson et al., (2007). Parallel regression lines were also compared using overlapping confidence limits $(p \leq 0.05)$ of relative potencies as the criterion to detect significant differences in mortality. In Factorial experiments and germination tests, the data were statistically analyzed using one-way analysis of variance (ANOVA) followed by Tukey's honestly significant difference (HSD) test to determine statistical differences between means at $\alpha=0.05$. 


\section{RESULTS}

3.1 Susceptibility of canola, soybean and safflower to microwave radiation

The present study revealed that there is a reduction in germination rate of oilseeds after exposure to microwave power (Table 1). Based on overlapping fiducially limits, three oilseeds tested showed similar susceptibility to microwave radiation; however, slope of the probit-log dose line reveals that safflower has more natural mortality rate compared to the other oilseeds.

Table 1: Lethality of microwave radiations at 5-minute exposure duration to oilseeds

\begin{tabular}{lcccccc}
\hline \multicolumn{1}{c}{ Oilseed } & LD $_{50}$ (watt) & $95 \%$ FL & Slope \pm SEM & Chi-Square & df & Sig. \\
\hline G. max & 516 & $403-729$ & $1.077 \pm 0.183$ & 0.618 & 3 & 0.892 \\
C. tinctorius & 535 & $405-811$ & $0.957 \pm 0.179$ & 0.997 & 3 & 0.801 \\
B. napus & 622 & $483-913$ & $1.129 \pm 0.12$ & 0.185 & 3 & 0.681 \\
\hline
\end{tabular}

\subsection{Susceptibility of Aspergillus niger spores to microwave radiation}

This study proved that A. niger is susceptible to microwave radiation (Table 2). Based on the fiducially limit of $\mathrm{LD}_{50}$ values due to overlapping these limits, the three oilseeds' $A$. niger showed similar susceptibility to microwave stimuli. The slopes of regression lines provide sufficient evidence that the regression lines are parallel with different intercepts.

Table 2: Susceptibility of Aspergillus niger to microwave radiation at 5-minute exposure duration

\begin{tabular}{lcccccc}
\hline Oilseed & $\mathrm{LD}_{50}(\mathrm{watt})$ & $95 \%$ FL & Slope \pm SEM & Chi-Square & df & Sig. \\
\hline G. max & 1063 & $816-88901$ & $2.651 \pm 1.312$ & 1.687 & 2 & 0.43 \\
C. tinctorius & 716 & $189-1179$ & $1.315 \pm 0.413$ & 2.220 & 2 & 0.329 \\
B. napus & 1175 & $862-79021$ & $1.969 \pm 0.925$ & 0.343 & 2 & 0.842 \\
\hline
\end{tabular}

The unit 'watt' is a power rating in its own

\subsection{Interaction between power level and exposure duration}

The result reveals that a statistically significant interaction does not exist between microwave power level and exposure duration in the current study. Apparently, power levels have been differently hazardous to seed germination; and are more important to germination compared to exposure duration (Table 3). The lack of interaction of two factors implies that the power level with exposure period impact the $A$. niger independently. 
Table 3: Lethality of various microwave power levels and exposure duration on oilseeds germination

\begin{tabular}{|c|c|c|c|c|c|}
\hline Oilseed & Source & $\mathrm{df}$ & Mean Square & $\mathrm{F}$ & Sig. \\
\hline \multirow{8}{*}{ G. $\max$} & Corrected Model & 11 & 937.111 & 113.58 & 0.000 \\
\hline & Intercept & 1 & 21121.778 & 2560.215 & 0.000 \\
\hline & $\mathrm{A}$ & 5 & 2046.378 & 248.046 & 0.000 \\
\hline & $\mathrm{B}$ & 1 & 9.000 & 1.091 & 0.307 \\
\hline & $\mathrm{A} \times \mathrm{B}$ & 5 & 13.467 & 1.632 & 0.190 \\
\hline & Error & 24 & 8.250 & & \\
\hline & Corrected Total & 35 & & & \\
\hline & \multicolumn{5}{|c|}{ R Squared $=0.981$} \\
\hline \multirow{8}{*}{ C. tinctorius } & Corrected Model & 11 & 1088.657 & 72.443 & 0.000 \\
\hline & Intercept & 1 & 20832 & 1386.240 & 0.000 \\
\hline & $\mathrm{A}$ & 5 & 2381.044 & 158.433 & 0.000 \\
\hline & $\mathrm{B}$ & 1 & 25.000 & 1.664 & 0.209 \\
\hline & $\mathrm{A} \times \mathrm{B}$ & 5 & 9.00 & 0.599 & 0.701 \\
\hline & Error & 24 & 15.028 & & \\
\hline & Corrected Total & 35 & & & \\
\hline & \multicolumn{5}{|c|}{ R Squared $=0.957$} \\
\hline \multirow{8}{*}{ B. napus } & Corrected Model & 11 & 961.947 & 91.132 & 0.000 \\
\hline & Intercept & 1 & 19460.250 & 1843.603 & 0.000 \\
\hline & $\mathrm{A}$ & 5 & 2104.783 & 199.401 & 0.000 \\
\hline & $\mathrm{B}$ & 1 & 23.361 & 2.213 & 0.150 \\
\hline & $\mathrm{A} \times \mathrm{B}$ & 5 & 6.828 & 0.647 & 0.667 \\
\hline & Error & 24 & 10.556 & & \\
\hline & Corrected Total & 35 & & & \\
\hline & \multicolumn{5}{|c|}{ R Squared $=0.977$} \\
\hline
\end{tabular}

A: radiation power levels; B: radiation times

\subsection{Effect of microwave radiation on germination percentage and vigor index}

The germination percentage and vigor index of oilseeds were reduced as compared to healthy seeds of all the three types of tested seeds (Table 4). The reduction in germination percentage was observed after 7th day of both infested and healthy seeds. The reduction of seed germination compared to control group was $13 \%, 14 \%$ and $15 \%$ for soybean, canola, and safflower, respectively. Concerning vigor index of infested seeds, the index was 487, 136, and 106, respectively. While for control seeds, vigor index for soybean, canola, and safflower was 910, 694 and 203. As it is obvious there has been drastic reduction in seedling vigor indexes of infested and healthy seeds.

Overall, this study proved the ability of the microwaves period to kill the fungal colonies and do not allow for the growth of fungal spores, meaning that the rate of growth of fungal colonies is positively proportional to the microwaves power level.

Table 4: Effect of microwave radiation on germination percentage and vigor index of three oilseed crops

\begin{tabular}{|c|c|c|c|c|}
\hline \multicolumn{2}{|c|}{ Oil-seed } & G. max & C. tinctorius & B. napus \\
\hline \multirow{2}{*}{$\begin{array}{c}\text { Germination percentage } \\
\text { after } 7^{\text {th }} \text { day }\end{array}$} & Control & 99 & 94 & 86 \\
\cline { 2 - 5 } & Infested & 88 & 80 & 44 \\
\hline \multirow{2}{*}{ Vigor index after $7^{\text {th }}$ day } & Control & 910 & 203 & 694 \\
\cline { 2 - 5 } & Infested & 487 & 106 & 136 \\
\hline
\end{tabular}




\subsection{Microwave radiation and oil composition}

In 35 out of 36 cases, the effects of microwave radiation on oil composition were similar to those of control treatment (Table 5). Moreover, results display that for soybean and safflower; mean oil content is different from control cohorts, while in the case of canola no significant difference was detected between infested and healthy seeds (Table $6)$.

Table 5: Mean comparisons of oil compositions of G. max, C. tinctorius, and B. napus infested with A. niger and control group

\begin{tabular}{|c|c|c|c|c|c|c|c|c|c|c|c|c|}
\hline \multirow[b]{2}{*}{ Traits } & \multicolumn{12}{|c|}{ Fatty acid profile (\%) } \\
\hline & C14:0 & $\begin{array}{c}\text { C16: } \\
0\end{array}$ & C16:1 & C18:0 & C18:1 & $\begin{array}{c}\text { C18: } \\
2\end{array}$ & $\begin{array}{c}\mathrm{C} 18: 3 \\
\mathrm{n}\end{array}$ & $\mathrm{C} 20: 0$ & $\mathrm{C} 20: 1$ & C22:0 & $\begin{array}{c}\text { C24: } \\
0\end{array}$ & $\mathrm{C} 24: 1$ \\
\hline G. $\max$ & 0.079 & $\begin{array}{c}11.1 \\
7\end{array}$ & 0.099 & 3.747 & 17.44 & $\begin{array}{c}55.4 \\
6\end{array}$ & 9.913 & 0.322 & 0.232 & 0.336 & $\begin{array}{c}0.06 \\
4\end{array}$ & 0.163 \\
\hline Control & 0.135 & $\begin{array}{c}11.0 \\
9\end{array}$ & 0.144 & 3.741 & 18.33 & $\begin{array}{c}54.8 \\
4 \\
\end{array}$ & 9.642 & 0.381 & 0.279 & 0.344 & $\begin{array}{c}0.23 \\
6 \\
\end{array}$ & 0.160 \\
\hline$t$ & -0.99 & 0.28 & -0.68 & 0.10 & -1.16 & 3.92 & 3.01 & -0.76 & -0.83 & -0.31 & $\begin{array}{c}- \\
1.79\end{array}$ & 0.027 \\
\hline$p$ & 0.42 & 0.80 & 0.36 & 0.92 & 0.36 & $\begin{array}{c}0.05 \\
9\end{array}$ & 0.09 & 0.52 & 0.49 & 0.78 & $\begin{array}{c}0.21 \\
5\end{array}$ & 0.98 \\
\hline $\begin{array}{c}C . \\
\text { tinctorius }\end{array}$ & 0.14 & 6.47 & 0.069 & 2.351 & 13.79 & $\begin{array}{c}73.9 \\
9 \\
\end{array}$ & 0.368 & 0.215 & 0.43 & 0.69 & 0.27 & 0.364 \\
\hline Control & 0.15 & 6.63 & 0.095 & 2.36 & 14.05 & $\begin{array}{c}73.6 \\
5\end{array}$ & 0.401 & 0.281 & 0.26 & 0.69 & 0.23 & 0.254 \\
\hline$t$ & 1.33 & 1.30 & 0.79 & 0.64 & 0.38 & $\begin{array}{c}- \\
0.45\end{array}$ & 0.58 & 0.78 & -7.25 & 0.04 & 0.25 & -0.86 \\
\hline$p$ & 0.31 & 0.32 & 0.51 & 0.58 & 0.74 & 0.69 & 0.61 & 0.51 & 0.01 & 0.97 & 0.82 & 0.48 \\
\hline B. napus & 0.060 & 4.51 & 0.22 & 2.13 & 62.31 & $\begin{array}{c}17.9 \\
8\end{array}$ & 9.05 & 0.66 & 1.39 & 0.32 & 0.17 & 0.208 \\
\hline Control & 0.063 & 4.44 & 0.22 & 2.10 & 62.64 & $\begin{array}{c}17.6 \\
4 \\
\end{array}$ & 9.12 & 0.67 & 1.39 & 0.33 & 0.23 & 0.166 \\
\hline$t$ & -1.05 & 1.20 & -0.07 & 1.95 & -0.88 & 0.99 & -1.48 & -0.14 & 0.07 & -0.64 & $\begin{array}{c}- \\
1.51\end{array}$ & 1.26 \\
\hline$p$ & 0.40 & 0.35 & 0.94 & 0.19 & 0.46 & 0.42 & 0.27 & 0.90 & 0.94 & 0.58 & 0.27 & 0.33 \\
\hline
\end{tabular}

C14:0 myristic acid; C16:0 palmitic acid; $\mathrm{C} 16: 1$ palmitoleic acid; $\mathrm{C} 18: 0$ stearic acid; $\mathrm{C} 18: 1$ oleic acid; $\mathrm{C} 18: 2$ linoleic acid; C18:3n linolenic acid; C20:0 arachidic acid; C20:1 gadoleic acid; C 22:0 behenic acid; C24:0 lignoceric acid; C24:1 nevonic acid.

$t=\mathrm{t}$-test, $p=$ probability

Table 6: Effect of Aspergillus niger on oil content of three oilseed crops

\begin{tabular}{ccc}
\hline \multirow{2}{*}{ Oilseed } & \multicolumn{2}{c}{$\%$ Oil content in oilseeds } \\
\cline { 2 - 3 } & Control (Mean \pm S.E.) & Infested (Mean \pm S.E.) \\
\hline G. max & $19.64 \pm 0.41$ & $14.34 \pm 0.53^{*}$ \\
C. tinctorius & $32.27 \pm 0.43$ & $29.27 \pm 0.39^{*}$ \\
B. napus & $38.77 \pm 1.16$ & $37.32 \pm 1.03^{\text {ns }}$ \\
\hline
\end{tabular}

$* p \leq 0.05 ; \mathrm{ns}=$ not significant

\section{DISCUSSION}

Distinct characteristics such as faster heating rate and greater penetration in food stuff depth have made microwaves a unique tool for many industrial sanitation applications such as sterilization and disinfestations (Knutson et al., 1987). The mechanism of devastation of pathogens through microwaves is controversial. However, there is an anonymous agreement about the 
destructive effect of microwaves. In this line, Datta and Davidson (2000) reported that no pathogen had been reported to be microwave resistant. Nevertheless, similar to any other process, microwave applications have their own challenges. For instance, uneven temperature distribution is one of the problems with microwave applications under field conditions.

The test oilseeds are the main important source of vegetable oil in the world. For instance, soybeans and canola oils are first and second important edible oil resources worldwide. These oils are considered healthy for human nutrition due to their lowest content of saturated fatty acids among vegetable oils and moderate content of polyunsaturated fatty acids. In the present study, the oil quality of oilseeds was generally unaffected by microwave radiation. Although fatty acid profiles vary somewhat from sample to sample, they are widely used to characterize vegetable oils from particular species or varieties of plants (Ehernsing, 2008).

There is a drastic reduction in seedling vigor indexes of infested and healthy seeds. The results of current study confirmed the statement of Nargund et al. (2003) who argued that A. niger reduces germination percentage and vigor index in all genotype of Arachis hypogea. In order to analyze the influence of the factors (exposure time and power level) on the destruction rate for oilseed and spores, the empirical data were statistically analyzed. The probit analysis revealed that microwave radiation had a deleterious impact on oilseed viability (Table 3 ). The lack of statistically significant interaction most likely is due to short term exposure time. The reasoning behind is the lack of significant difference between two levels of the exposure period. Therefore, the extension of the exposure period is imperative and even inevitable action and must be done. The distinction between live seeds and germinated seeds is important since microwave radiation may cause injury by retarding germination as well as destruction of germinative capacity. Therefore, decreases in germination rate or seminal roots length after radiation was adequate to prove a deleterious effect of microwave radiation on oilseeds seed viability. A new approach in fungal control research could be the use of less hazardous substances or control methods, which are more compatible with environment. Method for the control strategies that are environmentally sustainable and avoid the use of conventional is of paramount important. Disinfestations fungal infestation stored-products with physical control methods such as using microwaves energy treatment can be an alternative measure to fungicide in controlling fungi.

Microwave power, as a powerful decontamination tool showed acceptable biological effectiveness against $A$. niger. With retrospect, due to sorption characteristics and deleterious effects on oilseed viability, microwave radiation may have only limited use in oilseed decontamination. Nevertheless, since microwave is highly toxic to $A$. niger, and because it is compatible with the environment, it could be considered as a potential compound for oilseed disinfestations. It is well established that a good control agent must kill the target organism with an acceptable level of the agent in a short period of time. Since, microwave's power is lethal to the A. niger, it could be considered as a potential tool which helps to reduce $A$. niger's development in any disinfestations programs.

\section{CONCULSIONS}

From the present study it was evident that Aspergillus niger was sensitive to microwave radiation. Its spores were killed. Oil quality was generally unaffected by microwave radiation, but microwave radiation had a deleterious impact on oilseeds seed viability. Also it can be concluded that more detailed studies are required to explore a safer and economic technique to evaluate seed borne fungi infestation potentials, to that exposed seeds' oil might be safe guarded. 


\section{ACKNOWLEDGEMENTS}

I would like to acknowledge Prof. A.A. Pourmirza, Dr. Y. Ghosta and Dr. Y. Rezaee Danesh for their constructive and useful comments.

\section{REFERENCES}

Afolabi I.M., Bisi-Adeniyi T.D., Adedoyin T.R., Rotimi S.O. 2015. Radiation and biodegradation techniques for detoxifying Carica papaya seed oil for effective dietary and industrial use. Journal of Food Science and Technology. 52: 6475-6483. Doi: 10.1007/s13197-014-1698-7

Bangash F.K., Ahmad S., Ahmad T., Atta S., Alam S. 2007. Effects of low dose gamma radiations on the stability of canola and sunflower oils. Journal of Chemistry Socitey of Pakistan. 29: 200-203.

Christof N., Misakyan M.A., Matafonova G.G., Barkhudarov E.M., Batoev V.B., Kossy I.A., Sharp J. 2008. UV treatment of microorganisms on artificially-contaminated surfaces using excimer and microwave UV lamps. Chemosphere. 73 (5): 717-722. Doi: 10.1016/j.chemosphere.2008.06.059

Datta A.K., Davidson P.M. 2000. Microwave and radio frequency processing. Journal of Food Science Supplement. Kinetics of Microbial Inactivation for Alternative Food Processing Technologies. 65 (Suppl.): 32-41. Doi: 10.1051/alr:1994009

Desvilettes C., Bourdier G., Breton J.C. 1994. Lipid class and fatty acid composition of planktivorous larval pike (Esoxlucius) living in a natural pond. Aquatic Living Resources. 7: 67-77.

Ehrensing D.T. 2008. Oilseed crops canola. Oregon State University Extension Service Circular EM8955- E.

Hallman G.J., Denlinger D.L. 1999. Temperature sensitivity and integrated pest management. In: Hallman, G.J. and Denlinger, D.L. (Eds). Temperature sensitivity in insects and application in integrated pest management. West View Press, Boulder, Colorado, pp: 1-5.

Knutson K.M., Marth E.H., Wagner M.K. 1987. Microwave heating of food. LebensmittleWissenschaft und -Technology 20: 101-110.
Kumar K.A., Viswanathan K. 2013. Study of the UV transmission through a few edible oils and chicken oil. Journal of Spectroscopy. 2013: 1-5. Doi: $10.1155 / 2013 / 540417$

ISTA (International Seed Testing Association). 1976. International rules for seed testing. Annex to Chapter 5: The germination test. Seed Science and Technology. (Supplement) 27: 27-32.

Movahhedy-Dehnavy M., Modarres-Sanavy S.A.M., Mokhtassi-Bidgoli A. 2009. Foliar application of zinc and manganese improves seed yield and quality of safflower (Carthamus tinctorius L.) grown under water deficit stress. Industrial Crops and Products Journal. 30: 82-92. Doi: 10.1016/j.indcrop.2009.02.004

Nargund V.B., Patil M.B., Deshpande V.K. 2003. Pod rot of groundnut and its impact on seed properties. In: Proceeding of the National Workshop on Groundnut Seed Technology, February 6-7, 2003, Dharwad, Raichur, USA. pp: 164-167.

Robertson J.L., Russell R.M., Preisler H.K. Savin, E. 2007. Bioassays with Arthropods. 2nd Rev. Ed., CRC press, Boca Ratone, FL.

SPSS Inc. 1993. SPSS for Windows User's Guide Release 6. SPSS Inc. Chicago. IL.

St.John L.C., Bell F.P. 1989. Extraction and fractionation of lipids from biological tissues, cell, organelles, and fluids. Biotechnology. 7: 476-481.

Vadivambal R., Jayas D.S. White N.D.G. 2007. Wheat disinfestations using microwave energy. Journal of Stored Products Research. 43: 508-514. Doi: 10.1016/j.jspr.2007.01.007

Wang S. Tang J. 2001. Radio frequency and microwaves alternative treatments for insect control in nuts. Journal of Agricultural Engineering. 10 (3): 105-120. 